\title{
Cytoskeleton-dependent Endocytosis Is Required for Apical Type 1 Angiotensin II Receptor-mediated Phospholipase C Activation in Cultured Rat Proximal Tubule Cells
}

\author{
Jeffrey R. Schelling, Alan S. Hanson, Rochelle Marzec, and Stuart L. Linas
}

University of Colorado Health Sciences Center, Denver, Colorado 80262

\begin{abstract}
Renal proximal tubule sodium reabsorption is enhanced by apical or basolateral angiotensin II (AII). Although AII activates phospholipase C (PLC) in other tissues, AII coupling to PLC on either apical or basolateral surfaces of proximal tubule cells is unclear. To determine if AII causes PLC activation, and the differences between apical and basolateral AII receptor function, receptors were unilaterally activated in rat proximal tubule cells cultured on permeable, collagen-coated supports. Apical AII incubation resulted in concentration- and time-dependent inositol trisphosphate $\left(\mathrm{IP}_{3}\right)$ formation. Basolateral AII caused greater IP $_{3}$ responses. Apical AII-induced IP $_{3}$ generation was inhibited by DuP 753, suggesting that the type 1 AII receptor subtype mediated proximal tubule PLC activation. Apical AII signaling did not result from paracellular ligand leak to basolateral receptors since AII-induced PLC activation occurred when basolateral AII receptors were occupied by SarLeu AII or DuP 753. Inhibition of endocytosis with phenylarsine oxide prevented apical (but not basolateral) AII-induced $\mathrm{IP}_{\mathbf{3}}$ formation. Cytoskeletal disruption with colchicine or cytochalasin $\mathrm{D}$ also prevented apical $\mathrm{AII}$-induced $\mathrm{IP}_{3}$ generation. These results demonstrate that in cultured rat proximal tubule cells, AII is coupled to PLC via type 1 AII receptors and cytoskeleton-dependent endocytosis is required for apical (but not basolateral) AII receptor-mediated PLC activation. (J. Clin. Invest. 1992. 90:2472-2480.) Key words: angiotensin II • proximal tubule $\bullet$ apical $\bullet$ signaling $\bullet$ endocytosis
\end{abstract}

\section{Introduction}

Angiotensin II (AII) ${ }^{1}$ has multiple physiological effects on sodium and fluid volume homeostasis. Although some of these effects are indirectly mediated by AII-induced aldosterone secretion and AII-induced contraction of the systemic and renal vasculature $(1,2)$, recent studies have revealed that AII di-

Portions of this manuscript were submitted in abstract form for presentation at the 24th Annual American Society of Nephrology Meeting,

Address correspondence and reprint requests to Stuart L. Linas, M.D., Department of Medicine, 777 Bannock St., Box 4000, Denver, CO 80204.

Received for publication 28 August 1991 and in revised form 17 June 1992.

1. Abbreviations used in this paper: AII, angiotensin II; AP, apical; $\mathrm{AT}_{1}$, type 1 AII receptor; BL, basolateral; DME F-12, DME and Ham's nutrient mixture F-12; $\mathrm{IP}_{3}$, inositol trisphosphate; PLC, phospholipase C.

J. Clin. Invest.

(c) The American Society for Clinical Investigation, Inc.

$0021-9738 / 92 / 12 / 2472 / 09 \quad \$ 2.00$

Volume 90, December 1992, 2472-2480 rectly enhances renal proximal tubule sodium reabsorption (3-7). Moreover, increased bicarbonate absorption was observed when AII was applied to either the apical (AP) or basolateral (BL) surface of isolated perfused proximal tubules (4). The BL AII response was anticipated because AII receptors ( 8 , 9) and signaling enzymes (10) are present on BL membranes. The AP AII response was somewhat unexpected because AII was assumed to primarily activate proximal tubules at BL sites, as filtered AII concentrations were thought to be low due to the presence of angiotensinases in brush border membranes. Furthermore, AII receptors on the AP membrane have been postulated to mediate ligand salvage, as well as receptor recycling and degradation (11), rather than signaling. This limited function of AP AII receptors also seemed logical since signaling enzymes appeared to be present on the BL proximal tubule cell membrane (10).

The signaling pathways that transduce AII activity in proximal tubule cells are controversial. Although microperfusion of rat proximal tubules with AII resulted in decreased adenylyl cyclase activity (12), the effect of AII on phospholipase C (PLC) is less clear. AII elicits PLC signals in most systems (13, 14 ), but the ability of AII to generate PLC signals in proximal tubule cells is uncertain. Some investigators have observed increased protein kinase $C$ activity (15), which may indicate prior PLC activation. Other studies have demonstrated no PLC response to AII in proximal tubule cells $(16,17)$.

Proximal tubule cells are polarized and contain AP and BL membranes with unique lipid, protein, and organelle distribution. Although AII receptors have been identified on AP and BL proximal tubule cell membranes prepared from intact kidneys $(8,9,18)$, the specific receptor (AP or BL) that could couple AII to PLC is not known. Furthermore, AII receptormediated endocytosis is required for AII activity in vascular smooth muscle (19) and adrenal glomerulosa (20) cells, but the role of endocytosis in AII-induced signal transduction from $\mathrm{AP}$ and $\mathrm{BL}$ receptors in proximal tubule cells is not known.

Until recently it has not been possible to selectively study AP versus BL receptor function because culture conditions favoring growth and differentiation of epithelial cells were not ideal. The principal problem had been that cells were grown on impermeable supports, such as plastic. Under these conditions, selective access to the BL surface was not possible because cells attach to supports along the BL membrane. Since the support surface was impermeable, agonists could not reach BL receptors. Furthermore, proximal tubule cells cultured on plastic exhibit impaired growth and differentiation because nutrient uptake occurs predominantly along the BL membrane (21). These technical problems have recently been overcome by the technique of culturing epithelial cells on permeable supports $(21,22)$. This method yielded proximal tubule cells with welldifferentiated AP and BL membranes and provided the opportunity to unilaterally activate AII receptors by selectively exposing agonist to one membrane, but not the other. 
The purposes of our study, therefore, were to determine whether AII is coupled to PLC in cultured rat proximal tubule cells, to identify whether AII-induced PLC activation was mediated by AP or BL AII receptors, and to establish differences between AP and BL AII receptor requirements for signaling.

\section{Methods}

Proximal tubule cell isolation and culture. The technique of proximal tubule cell isolation was derived from Vinay et al. (23) with few modifcations. Kidneys were excised from male Sprague-Dawley rats without perfusion, minced, and digested with collagenase $(272 \mathrm{U} / \mathrm{ml})$ for 30 $\min$ at $37^{\circ} \mathrm{C}$. The supernatant was discarded and digestion was terminated by incubating the pellet with $2.5 \%$ albumin in isolation solution ( $135 \mathrm{mM} \mathrm{NaCl}, 5 \mathrm{mM} \mathrm{KCl}, 0.8 \mathrm{mM} \mathrm{MgSO}_{4}, 0.3 \mathrm{mM} \mathrm{Na}_{2} \mathrm{HPO}_{4}, 0.4$

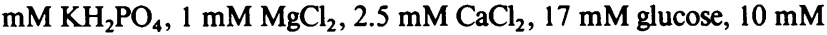
Hepes, $100 \mathrm{U} / \mathrm{ml}$ penicillin $\mathrm{G}, 100 \mu \mathrm{g} / \mathrm{ml}$ streptomycin sulfate, $\mathrm{pH}$ 7.20) on ice. Glomeruli were excluded from the cell suspension by sieving through sterile wire mesh. Proximal tubule cells were separated from the remainder of the pellet by Percoll gradient centrifugation. The proximal tubule cell band was extracted and washed with sterile isolation solution and then mixed with DME and Ham's nutrient mixture F-12 (DME F-12) containing 6.5 $\mu \mathrm{M}$ transferrin, $87 \mu \mathrm{M}$ insulin, 10 $\mu \mathrm{M}$ dexamethasone, $1.7 \mathrm{nM}$ epidermal growth factor, $14.3 \mathrm{mM}$ $\mathrm{NaHCO}_{3}, 10 \%$ bovine calf serum, $100 \mathrm{U} / \mathrm{ml}$ penicillin $\mathrm{G}, 100 \mu \mathrm{g} / \mathrm{ml}$ streptomycin, and $5 \mathrm{mM}$ MEM nonessential amino acid solution, $\mathrm{pH}$ 7.4. Cells were plated on $24.5-\mathrm{mm}, 0.4-\mu \mathrm{m}$ pore-permeable supports (3412; Costar Corp., Cambridge, MA), which were prewetted with type I collagen and suspended in six-well, $35-\mathrm{mm}$ cell culture cluster dishes (3416; Costar Corp.). The BL surface was bathed with $10 \%$ bovine calf serum in DME F-12. Attempts to culture cells on Matrigel yielded monolayers that never reached confluence. Media was changed every 3-4 d, and cells achieved confluence within 5-7 d.

Electron microscopy. Confluent proximal tubule cell monolayers on permeable supports were prepared for transmission electron microscopy by fixing with $2 \%$ glutaraldehyde in $0.1 \mathrm{M}$ cacodylate ( $\mathrm{pH} 7.35$ ) for $1 \mathrm{~h}$ at $21^{\circ} \mathrm{C}$. Cells were then washed twice with $0.1 \mathrm{M}$ cacodylate for $15 \mathrm{~min}$ and fixed in $1 \%$ osmium tetroxide/ $0.1 \mathrm{M}$ cacodylate for $30 \mathrm{~min}$ at $21^{\circ} \mathrm{C}$. The fixed specimen was washed twice with deionized water for $10 \mathrm{~min}$, dehydrated in ethanol, and imbedded in epon. Ultrathin sections were made and counterstained with uranyl acetate and lead citrate. Cells were observed with an electron microscope (Philips Electronic Instruments, Co., Mahwah, NJ).

Measurement of sodium transport. Unidirectional AP to BL sodium transport was determined by adding ${ }^{22} \mathrm{Na}(2 \mu \mathrm{Ci} / \mathrm{ml})$ with or without $10^{-7} \mathrm{M}$ AII to buffer solution containing the following $(\mathrm{mM})$ : $117 \mathrm{NaCl}, 5.4 \mathrm{KCl}, 1.8 \mathrm{CaCl}_{2}, 0.8 \mathrm{MgSO}_{4}, 0.9 \mathrm{NaH}_{2} \mathrm{PO}_{4}, 5.6$ glucose, $25 \mathrm{NaHCO}_{3}, 10$ Hepes, $1.0 \mathrm{PMSF}, \mathrm{pH} 7.40,21^{\circ} \mathrm{C}$ ), which was then incubated with the AP surface. The BL surface was bathed in the same buffer solution without PMSF or ligand. The contents of the entire plate were rocked by platform mixer at $100 \mathrm{rpm}$. Time zero was defined as the time when AP buffer was added. Aliquots of $5 \mu \mathrm{l}$ were sampled by microsyringe from the BL buffer at 5-, 10-, 20-, and 30-min intervals. ${ }^{22} \mathrm{Na}$ was quantified by liquid scintillation and ${ }^{22} \mathrm{Na}$ mass was calculated from a simultaneously determined standard curve. ${ }^{22} \mathrm{Na}$ transport was determined by dividing ${ }^{22} \mathrm{Na}$ mass by permeable support surface area. Results were expressed in $\mathrm{fmol} / \mathrm{mm}^{2}$.

Measurement of cyclic AMP. Cyclic AMP concentrations were determined by a competitive binding assay. After agonist incubation for 7 min at $21^{\circ} \mathrm{C}$, proximal tubule cells cultured on $6.5-\mathrm{mm}, 0.4-\mu \mathrm{m}$ pore permeable supports (3427; Costar Corp.) were lysed with $0.01 \mathrm{~N} \mathrm{HCl}$. The supernatant was then incubated with $100 \mu \mathrm{l}{ }^{125} \mathrm{I}$-cyclic AMP and $100 \mu \mathrm{l}$ antiserum at $4^{\circ} \mathrm{C}$ for $3 \mathrm{~h}$. The suspension was then incubated with a second antibody (which is bound to polymer particles) at $21^{\circ} \mathrm{C}$ for $10 \mathrm{~min}$ and centrifuged at $1,500 \mathrm{~g}$ for $10 \mathrm{~min}$. The supernatant was discarded, leaving the antibody-bound fraction. ${ }^{125} \mathrm{I}$ was determined by gamma scintillation, and cyclic AMP values were calculated from a simultaneously determined standard curve. Results were reported in picograms per milligram protein. Total protein was determined by the Lowry method (24). The final protein value was determined by subtracting protein content of collagen-coated wells without cells from total protein.

Measurement of inositol trisphosphate $\left(I P_{3}\right) . \mathrm{IP}_{3}$ was determined as previously reported by our laboratory for vascular smooth muscle cells (25). When proximal tubule cell monolayers were almost confluent, medium was changed to $10 \%$ bovine calf serum in inositol-deficient growth medium with $2.4 \mu \mathrm{Ci} / \mathrm{ml}$ myo- $\left[2-{ }^{3} \mathrm{H}\right]$ inositol $(2 \mathrm{ml} /$ well $)$ for $48 \mathrm{~h}$ at $37^{\circ} \mathrm{C}$. Preliminary studies revealed that incorporation of myo$\left[2-{ }^{3} \mathrm{H}\right]$ inositol equilibrated at $48 \mathrm{~h}$. After this incubation period, wells were washed with phosphate buffered saline at $21^{\circ} \mathrm{C}$ to remove unincorporated tracer. Agonists were dissolved in buffer ( $50 \mathrm{mM}$ Tris base, $50 \mathrm{mM}$ Tris hydrochloride, $100 \mathrm{mM} \mathrm{NaCl}, 10 \mathrm{mM} \mathrm{KCl}, 10 \mathrm{mM}$ $\mathrm{MgCl}_{2}, 1 \%$ albumin, $10,000 \mathrm{U} / \mathrm{ml}$ bacitracin, $\mathrm{pH} 7.40$ ) and added to $\mathrm{AP}$ or BL surfaces for indicated times at $21^{\circ} \mathrm{C}$. Reactions were terminated by addition of equal volumes of $20 \%$ trichloroacetic acid. The resulting suspension was removed by scraping the permeable support surface and centrifuging the contents at $400 \mathrm{~g}$ for $10 \mathrm{~min}$. The supernatant was extracted three times with equal volumes of diethyl ether and the aqueous phase was frozen at $-20^{\circ} \mathrm{C}$. Samples were thawed, $\mathrm{pH}$ was adjusted to 7 with $50 \mathrm{mM}$ Tris base, and samples were applied to $2-\mathrm{cm}$ AG1-X8 anion exchange resin columns at $21^{\circ} \mathrm{C}$. Inositol phosphates were measured by anion-exchange column chromatography according to the method of Berridge et al. (26) with sequential elutions with 0.2 $\mathrm{M}$ ammonium formate in $0.1 \mathrm{M}$ formic acid $\left(\mathrm{IP}_{1}\right), 0.5 \mathrm{M}$ ammonium formate in $0.1 \mathrm{M}$ formic acid $\left(\mathrm{IP}_{2}\right)$, and $1.0 \mathrm{M}$ ammonium formate in $0.1 \mathrm{M}$ formic acid $\left(\mathrm{IP}_{3}\right)$. Each fraction was quantified for ${ }^{3} \mathrm{H}$ by liquid scintillation. $\mathrm{IP}_{3}$ values were expressed as percent of baseline (the ratio of $\mathrm{IP}_{3}$ content in agonist-exposed cells to $\mathrm{IP}_{3}$ content in cells exposed only to Tris buffer).

Materials. Materials were obtained from the following sources: Sigma Chemical Co. (St. Louis, MO), DME F-12, Tris base, Tris hydrochloride, AII, Sar-Leu AII, type I collagen, wire mesh, arginine vasopressin, colchicine, cytochalasin $\mathrm{D}$, trichloroacetic acid, sodium formate, transferrin, insulin, dexamethasone, epidermal growth factor, penicillin G/streptomycin, MEM nonessential amino acid solution, ammonium formate, formic acid, sodium chloride, potassium chloride, magnesium sulfate, sodium phosphate, potassium phosphate, magnesium chloride, calcium chloride, glucose, Hepes, sodium bicarbonate, and PMSF; SASCO (Omaha, NE), Sprague-Dawley rats; Worthington Biochemical Corp. (Freehold, NJ), collagenase; Pharmacia LKB Biotechnology Inc. (Uppsala, Sweden), Percoll; Hazelton Research Products (Denver, PA), inositol-deficient DME; Collaborative Research (Bedford, MA), Matrigel; Fluka Chemical Corp. (Ronkonkoma, NY), phenylarsine oxide; Fisher Scientific (Fair Lawn, NJ), sodium borate, diethyl ether; Hyclone Laboratories Inc. (Logan, UT), bovine calf serum; American Radiolabeled Chem. Inc. (St. Louis, MO), myo- $\left[2-{ }^{3} \mathrm{H}\right]$ inositol; Amersham Corp. (Arlington Heights, IL), cyclic AMP assay kit, ${ }^{22} \mathrm{Na},\left[{ }^{14} \mathrm{C}\right]$ inulin; Barnstead/Thermolyne Corp. (Dubuque, IA), RotoMix platform mixer, type 48200; Hamilton Co. (Reno, NV), microsyringe 1700; Bio-Rad Laboratories (Richmond, CA), Dowex AG1-X8 anion exchange resin; Packard Instrument Co., Inc., United Technologies (Downers Grove, IL), Optifluor scintillation fluid. DuP 753 was a gift from Ronald D. Smith, E.I. DuPont de Nemours (Wilmington, DE).

Statistics. Results are expressed as the mean \pm SE. Comparison of ${ }^{22} \mathrm{Na}$ transport between AII and control groups was made by the unpaired, two-tailed Student's $t$ test. All other comparisons were made by one-way analysis of variance with the Scheffe test for multiple comparisons. Statistical significance is defined as $P<0.05$.

\section{Results}

Initial studies were performed to confirm the presence of pure proximal tubule cell monolayers. Fig. 1 is a representative elec- 

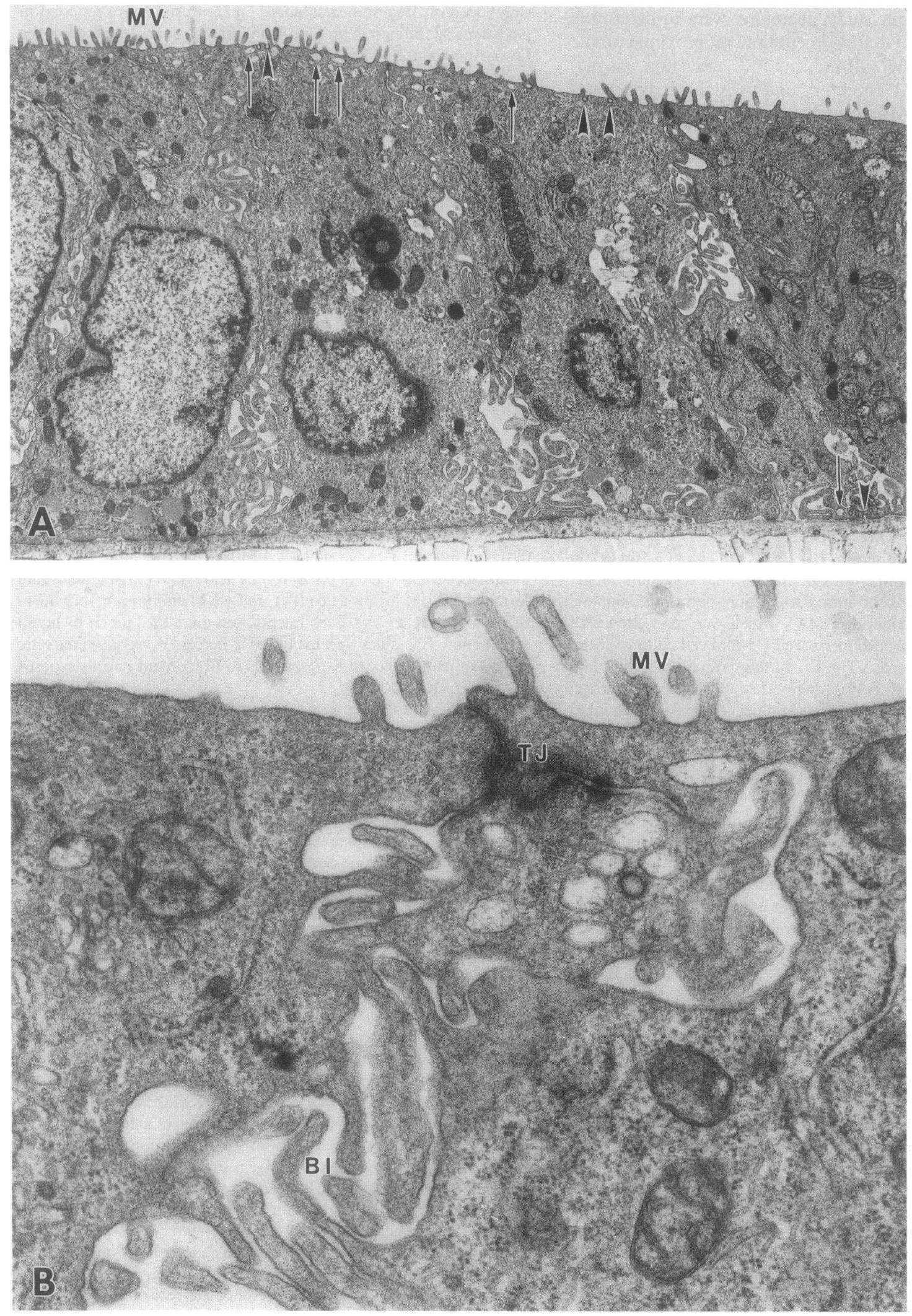

Figure 1. Representative transmission electron micrographs of confluent proximal tubule cell monolayers on permeable supports at $5 \mathrm{~d}$ of growth. $(A) \times 9,000, M V$, apical microvilli, arrowheads, coated pits, $\uparrow$, endosomes. $(B) \times 60,000, M V$, apical microvilli, $T J$, tight junctions, $B I$, basolateral infoldings. 
tron micrograph of rat proximal tubule cells cultured on permeable supports for $5 \mathrm{~d}$. Characteristic proximal tubule cell features include cuboidal to columnar cells with AP microvilli, BL infoldings, and bipolar organelle distribution. Of note is the relatively greater density of AP-coated pits and endosomes, as well as the presence of distinct intercellular tight junctions. To characterize the functional properties of the cells, cyclic AMP levels were measured after $\mathrm{AP}$ incubation with various hormones (Fig. 2). PTH caused concentration-dependent cyclic AMP increases $\left(10^{-9} \mathrm{M}\right.$ PTH: $P<0.01$ compared with control), arginine vasopressin caused no change in cyclic AMP, and AII elicited concentration-dependent cyclic AMP decreases ( $10^{-6} \mathrm{M}$ AII: $P=0.09$ compared with control). These data were consistent with known proximal tubule cell responses to each hormone (12, 27-29). Further elucidation of proximal tubule cell function was provided by ${ }^{22} \mathrm{Na}$ transport studies. Fig. 3 demonstrates that coincubation of AP $10^{-7} \mathrm{M}$ AII with tracer amounts of ${ }^{22} \mathrm{Na}$ resulted in time-dependent ${ }^{22} \mathrm{Na}$ flux in an AP to BL direction $(P<0.05$ compared with control at 20 and $30 \mathrm{~min}$ ).

Our next studies were designed to determine if AII generated PLC signals in proximal tubule cells. Fig. 4 demonstrates that AP or BL addition of AII resulted in PLC signals, as evidenced by increases in $\mathrm{IP}_{3}$. There were concentration-dependent effects of AP AII, with a threshold of $10^{-8} \mathrm{M}$ AII and a $14.5 \pm 2.8 \% \mathrm{IP}_{3}$ increase with $10^{-7} \mathrm{M}$ AII $(P<0.01$ compared with baseline, baseline $=544.3 \pm 52.7 \mathrm{cpm}$ per well $)$. BL addition of AII also elicited concentration-dependent PLC signals, with a $26.6 \pm 6.1 \%$ increase in $\mathrm{IP}_{3}$ at $10^{-7} \mathrm{M}$ AII $(P<0.05$ compared with baseline, baseline $=595.0 \pm 69.1 \mathrm{cpm}$ per well $)$. Fig. 5 demonstrates the time dependency of AP AII-induced $\mathrm{IP}_{3}$ signaling. The peak response was observed at $30 \mathrm{~s}$ $\left(15.7 \pm 5.9 \% \mathrm{IP}_{3}\right.$ increase above baseline, baseline $=613.9 \pm 72.1$ $\mathrm{cpm}$ per well). Thereafter, the $\mathrm{IP}_{3}$ response slowly declined by 60 and $90 \mathrm{~s}$ of $\mathrm{AII}$ incubation. By $10 \mathrm{~min}, \mathrm{IP}_{3}$ levels were less than baseline values. These data suggest that AII receptors are coupled to PLC in proximal tubule cells.

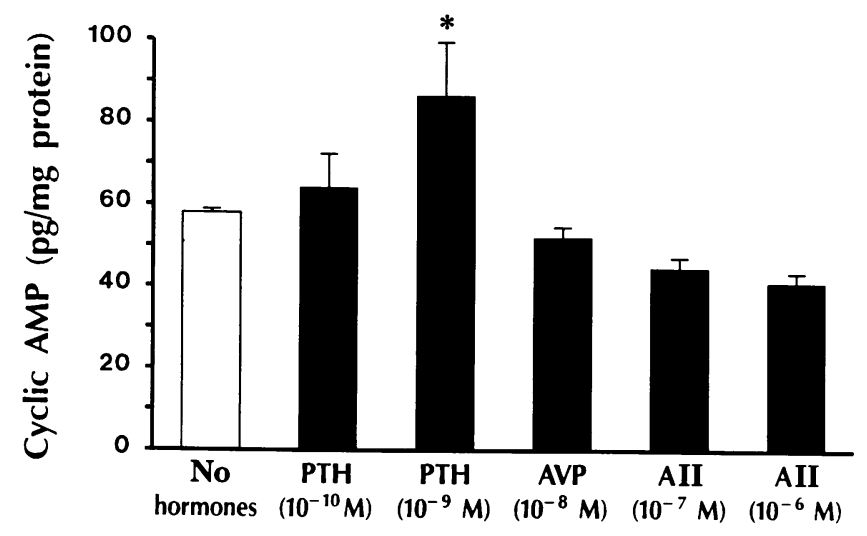

Figure 2. Effect of AP parathyroid hormone (PTH), arginine vasopressin $(A V P)$, and angiotensin II $(A I I)$ on proximal tubule cell cyclic AMP concentration. Hormones $\left(10^{-9} \mathrm{M}\right.$ PTH and $10^{-10} \mathrm{M}$ PTH, $10^{-8} \mathrm{M}$ AVP, $10^{-6} \mathrm{M}$ AII, and $10^{-7} \mathrm{M}$ AII ) or Tris buffer were incubated with the AP proximal tubule cell surface for $7 \mathrm{~min}$ at $37^{\circ} \mathrm{C}$. Reactions were terminated by addition of $0.01 \mathrm{~N} \mathrm{HCl}$. Cyclic AMP levels were determined by competitive antibody binding assay as described in Methods. Results are means of four experiments. ${ }^{*} P<0.01$ compared with group with no hormone incubation.

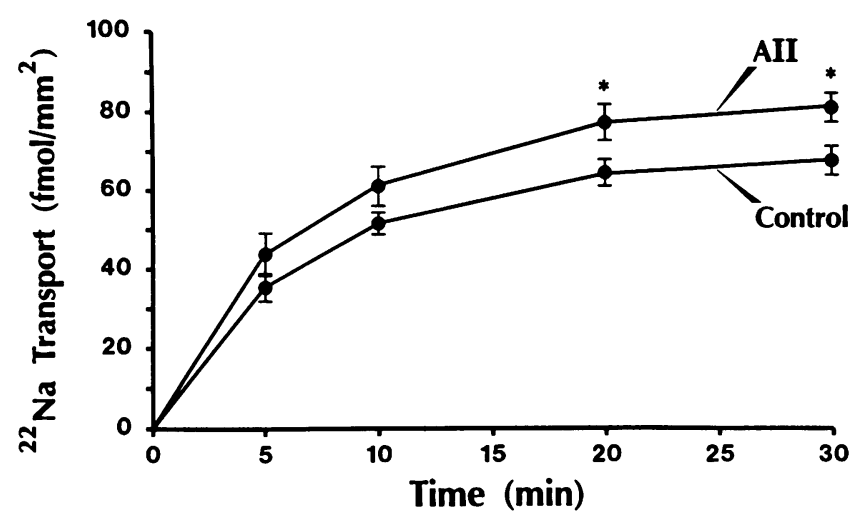

Figure 3. Effect of AP AII on proximal tubule ${ }^{22} \mathrm{Na}$ transport. Unidirectional $\mathrm{AP}$ to $\mathrm{BL}{ }^{22} \mathrm{Na}$ transport was determined in the presence or absence of $10^{-7} \mathrm{M}$ AP AII as described in Methods. Results are means of nine experiments. ${ }^{*} P<0.05$ compared with controls.

To determine whether AII receptors were functionally type 1 AII $\left(\mathrm{AT}_{1}\right)$ receptors, proximal tubule cells were exposed to AII in the presence of the specific nonpeptide $\mathrm{AT}_{1}$ antagonist DuP 753. Fig. 6 demonstrates that preincubation with DuP 753 in the AP buffer prevented AP AII-induced $\mathrm{IP}_{3}$ formation (baseline $=731.2 \pm 84.6 \mathrm{cpm}$ per well). The data suggest that $\mathrm{AT}_{1}$ receptors transduce PLC activation in proximal tubule cells.

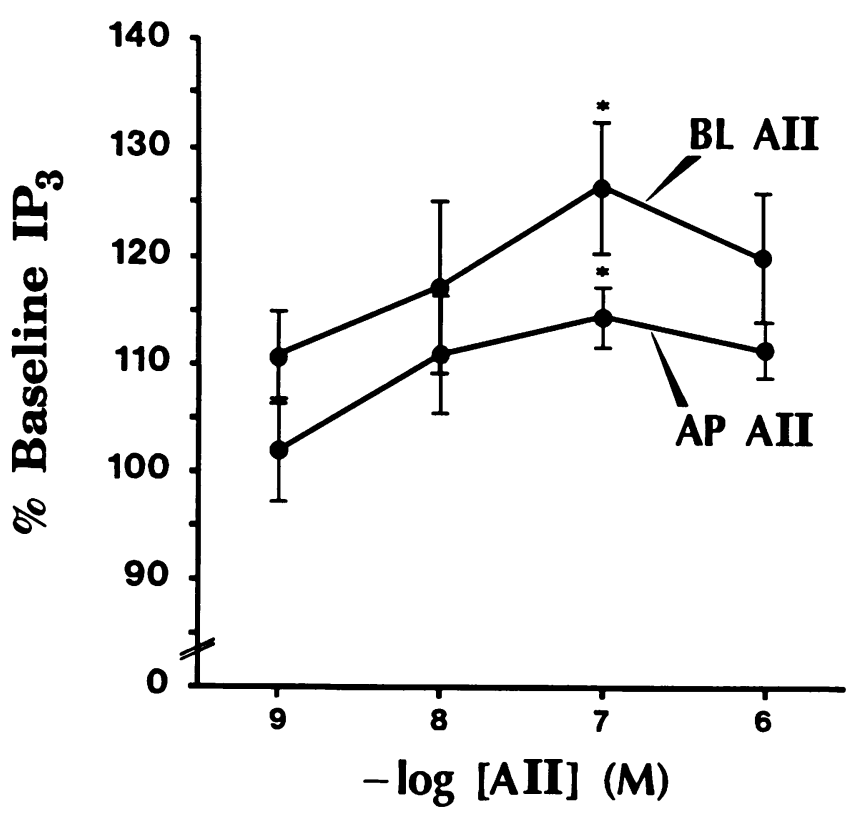

Figure 4. Effect of AII concentration on $\mathrm{IP}_{3}$ formation. Subconfluent proximal tubule cell monolayers on permeable supports were incubated with $10 \%$ bovine calf serum in inositol-deficient media containing myo- $\left[2-{ }^{3} \mathrm{H}\right]$ inositol for $48 \mathrm{~h}$ at $37^{\circ} \mathrm{C}$ as described in Methods. Confluent cell monolayers were washed with phosphate-buffered saline and exposed to the indicated concentrations of AP or BL AII versus Tris buffer for $30 \mathrm{~s}$ at $21^{\circ} \mathrm{C}$. Reactions were terminated by addition of $20 \%$ trichloroacetic acid. Cell suspensions were extracted in diethyl ether and the aqueous phase was applied to anion-exchange columns. Inositol phosphates were serially eluted with $0.2,0.4$, and $1.0 \mathrm{M}$ ammonium formate in $0.1 \mathrm{M}$ formic acid and quantified for ${ }^{3} \mathrm{H}$ by liquid scintillation. Results are means of four to eight experiments. ${ }^{*} P<0.01$ compared with baseline (Tris buffer without AII). 


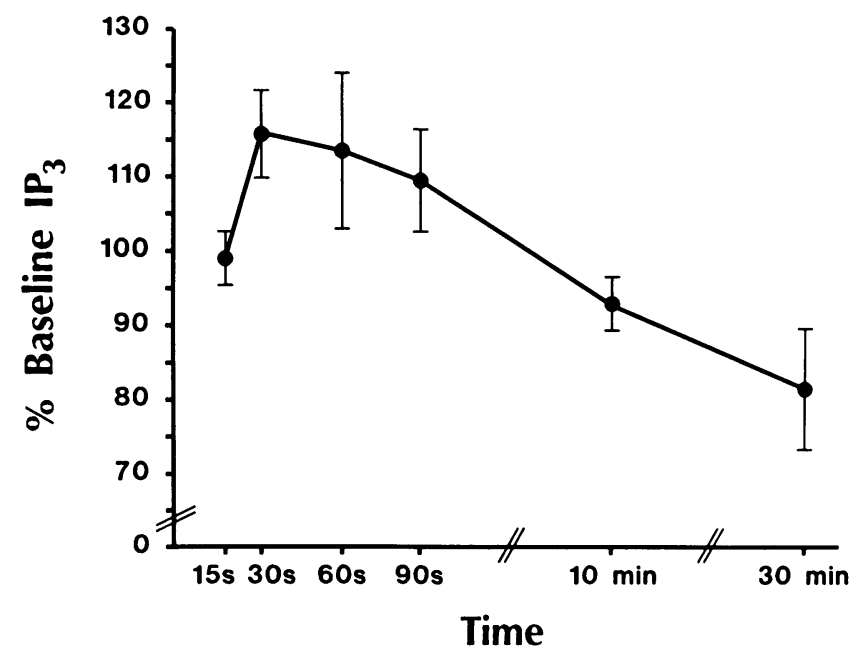

Figure 5. Effect of incubation time with AP AII on $\mathrm{IP}_{3}$ formation. Subconfluent proximal tubule cell monolayers on permeable supports were incorporated with myo- $\left[2-{ }^{3} \mathrm{H}\right]$ inositol as described in Methods. The AP proximal tubule cell surface was incubated for the indicated times with $10^{-7} \mathrm{M}$ AII at $21^{\circ} \mathrm{C}$. $\mathrm{IP}_{3}$ was extracted and measured as described in Methods. Results are means of three to seven experiments.

Although AII receptors have been identified on AP membranes prepared from proximal tubules $(8,9)$, AP receptors have previously been noted to be primarily degradative receptors (11). Since AII elicited PLC signals from AP as well as BL sites, we next sought to determine whether the AP signal was mediated by AP receptors or by paracellular leak of AII from AP to BL sites. Fig. 1 demonstrates the presence of well-defined tight junctions between adjacent PT cells, thereby making paracellular leak unlikely. Additional evidence against paracellular ligand leak is shown in Table I. When $\left[{ }^{14} \mathrm{C}\right]$ inulin or $\left[{ }^{3} \mathrm{H}\right]-$

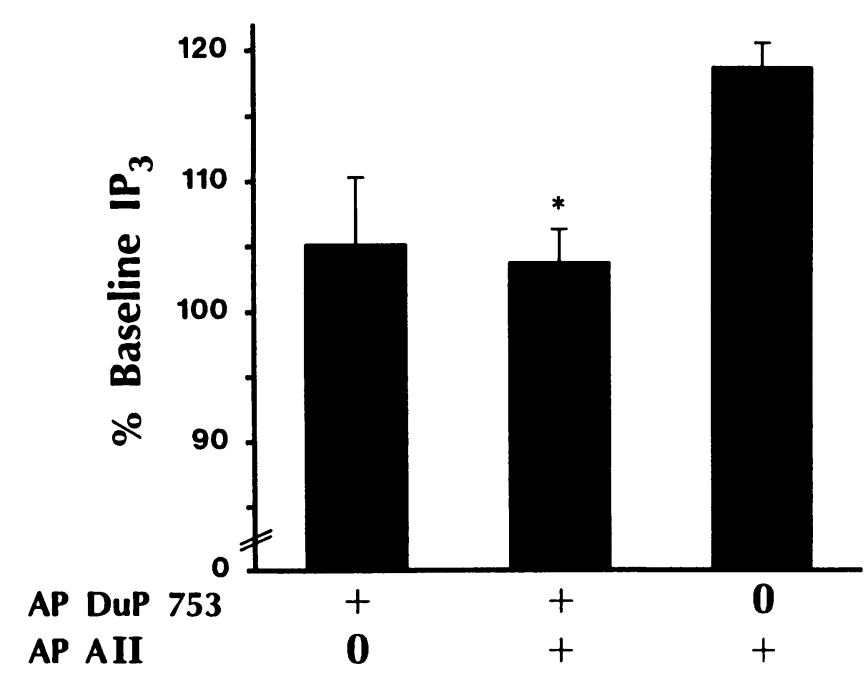

Figure 6. Effect of AP DuP 753 preincubation on AP AII-induced $\mathrm{IP}_{3}$ formation. Confluent proximal tubule cell monolayers on permeable supports that were previously incorporated with myo- $\left[2-{ }^{3} \mathrm{H}\right]$ inositol (see Methods) and then incubated with AP $10^{-6} \mathrm{M}$ DuP 753 or Tris buffer for $20 \mathrm{~min}$ at $21^{\circ} \mathrm{C}$. Cells were then washed with phosphate-buffered saline and exposed to AP $10^{-7} \mathrm{M}$ AII or Tris buffer for $30 \mathrm{~s}$ at $21^{\circ} \mathrm{C}$. $\mathrm{IP}_{3}$ was extracted and measured as described in Methods. Results are means of five or six experiments. ${ }^{*} P<0.05$ compared with AP AII alone.
Table I. Percent $\left[{ }^{14}\right.$ C]Inulin and $\left[{ }^{3}\right.$ H]Inositol in BL Buffer after Addition to AP Buffer

\begin{tabular}{rcc}
\hline Time & Percent AP ${ }^{14} \mathrm{C}$ dose $(n=5)$ & Percent AP ${ }^{3} \mathrm{H}$ dose $(n=4)$ \\
\hline $\min$ & & \\
0 & 0 & 0 \\
30 & $0.5 \pm 0.5$ & $3.5 \pm 0.6$ \\
60 & $1.7 \pm 0.5$ & $5.8 \pm 1.2$ \\
90 & $2.4 \pm 1.3$ & $7.9 \pm 1.8$ \\
120 & $3.2 \pm 1.8$ & $\mathrm{ND}$ \\
\hline
\end{tabular}

BL, basolateral; AP, apical.

inositol was added to the AP buffer, negligible amounts of radioisotope were identified in the BL buffer after $90 \mathrm{~min}$ of incubation. This degree of leak was considered particularly insignificant because AP AII incubations were only $30 \mathrm{~s}$ in duration. To further exclude the possibility of paracellular AII leak, the $\mathrm{IP}_{3}$ response to AP AII was determined in the presence of BL AII receptor occupancy with the peptide AII antagonist Sar-Leu AII (Fig. $7 A$ ) or the nonpeptide antagonist DuP 753 (Fig. $7 \mathrm{~B}$ ). When $10^{-7} \mathrm{M}$ Sar-Leu AII was exposed to the BL proximal tubule cell surface, small increases $(6.2 \pm 4.1 \%$ above baseline, baseline $=555.2 \pm 44.6 \mathrm{cpm}$ per well $)$ in $\mathrm{IP}_{3}$ were observed (Fig. $7 \mathrm{~A}$ ). This partial agonist effect was more pronounced at higher concentrations of Sar-Leu AII (data not shown). Nevertheless, even in the presence of BL Sar-Leu AII, AP AII incubation resulted in additional increases in $\mathrm{IP}_{3}$ formation $(P<0.05$ compared with baseline $)$. There was no significant difference between AP AII-induced $\mathrm{IP}_{3}$ generation in the presence or absence of BL Sar-Leu AII. Because Sar-Leu AII elicited a small agonist effect, we performed studies with a

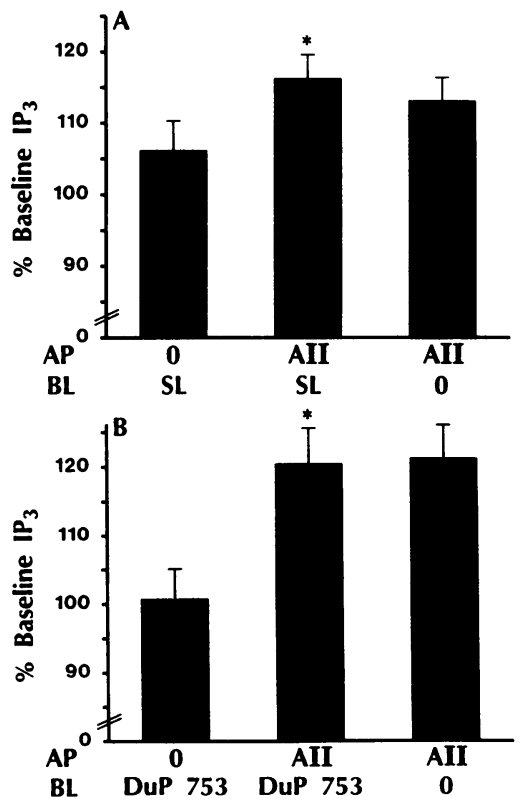

Figure 7. Effect of basolateral $(B L)$ Sar-Leu AII $(S L)$ or BL DuP 753 on AP AII stimulation of $\mathrm{IP}_{3}$. Proximal tubule cells were incorporated with myo- $[2-$ ${ }^{3} \mathrm{H}$ ] inositol as described in Methods. In $A$, the BL surfaces of confluent proximal tubule cell monolayers on permeable supports were incubated with $10^{-7} \mathrm{M}$ Sar-Leu AII or Tris buffer for $30 \mathrm{~min}$ at $21^{\circ} \mathrm{C}$. AP and BL surfaces were washed with phosphate-buffered saline and the AP proximal tubule cell surface was then incubated with $10^{-7} \mathrm{M}$ AII or Tris buffer for $30 \mathrm{~s}$ at $21^{\circ} \mathrm{C}$ $\mathrm{IP}_{3}$ was extracted and measured as described in Methods. Results are the means of three to seven experiments. $B$ is similar to $A$ except for preincubation with BL $10^{-6} \mathrm{M}$ DuP 753 (instead of Sar-Leu AII) or Tris buffer for $20 \mathrm{~min}$ at $21^{\circ} \mathrm{C}$. Results are means of three to five experiments. ${ }^{*} P<0.05$ compared with baseline. 
structurally dissimilar nonpeptide antagonist. Fig. $7 B$ shows that BL DuP 753 did not elicit $\mathrm{IP}_{3}$ signals. Moreover, in the presence of BL DuP 753, AP AII caused a $19.7 \% \mathrm{IP}_{3}$ increase ( $P<0.05$ compared with baseline), which was comparable to the $\mathrm{IP}_{3}$ signal from the AP surface without the $\mathrm{BL}$ antagonist $\left(20.5 \% \mathrm{IP}_{3}\right.$ increase above baseline, baseline $=678.0 \pm 66.3$ cpm per well). Taken together, these data exclude paracellular leakage of AP ligand to BL sites and suggest that AP AII receptors activate PLC.

Since AII signaling appears to require AII receptor-mediated endocytosis in vascular smooth muscle (19) and adrenal glomerulosa cells (20), we questioned whether AP AII receptors directly activated PLC or required endocytosis before activation of PLC. Fig. 8 demonstrates the effect of phenylarsine oxide (a trivalent oxidizing agent that prevents AII receptormediated endocytosis by binding to receptor sulfhydryl groups $[19,20,30])$ on AP and BL AII receptor-mediated PLC activation. When the AP proximal tubule surface was preincubated with phenylarsine oxide (Fig. $8 \mathrm{~A}$ ), complete inhibition of AP AII-induced $\mathrm{IP}_{3}$ formation was observed $(3.2 \pm 5.4 \%$ below baseline, $P<0.05$ compared with AII alone, baseline $=596.4 \pm 55.3$ $\mathrm{cpm}$ per well ). In contrast to the AP surface, addition of phenylarsine oxide to the BL buffer (Fig. $8 \mathrm{~B}$ ) did not prevent BL AII-induced $\mathrm{IP}_{3}$ formation $(25.3 \pm 3.9$ vs. $21.3 \pm 5.4 \%$ above baseline, baseline $=648.4 \pm 46.4 \mathrm{cpm}$ per well $)$. Since BL AIIinduced $\mathrm{IP}_{3}$ formation was preserved in the presence of phenylarsine oxide, these data demonstrated that phenylarsine oxide was not toxic. Furthermore, the studies also demonstrated a disparity between AP and BL AII receptor function. Whereas BL receptors were directly coupled to PLC, AP AII or AII receptors required endocytosis before generating PLC signals.

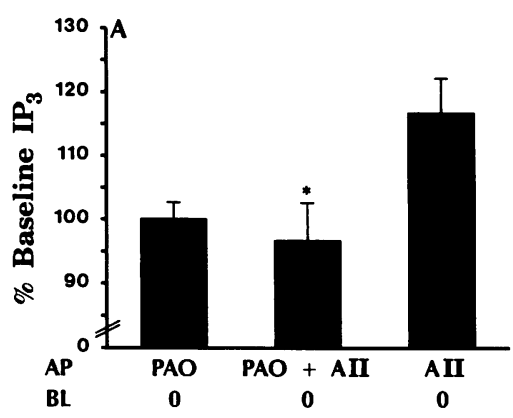

Figure 8. Effect of AP or BL phenylarsine oxide $(P A O)$ on ipsilateral AII-stimulated $\mathrm{IP}_{3}$ formation. Proximal tubule cells were incorporated with myo$\left[2^{-3} \mathrm{H}\right]$ inositol as described in Methods. In $A$, the AP surfaces of confluent proximal tubule cell monolayers on permeable supports were incubated with $10^{-4} \mathrm{M}$ PAO or Tris buffer for $20 \mathrm{~min}$ at $21^{\circ} \mathrm{C}$, washed, and exposed to AP $10^{-7} \mathrm{M}$ AII or Tris buffer for 30 s at $21^{\circ} \mathrm{C}$. The BL surface was incubated with Tris buffer throughout the experiment. $\mathrm{IP}_{3}$ was extracted and assayed as described in Meth-

ods. Results are means of four or five experiments. In $B$, the BL surfaces of confluent proximal tubule cell monolayers were incubated with $10^{-4} \mathrm{M}$ PAO or Tris buffer for $20 \mathrm{~min}$ at $21^{\circ} \mathrm{C}$, washed, and exposed to BL $10^{-7} \mathrm{M}$ AII for $30 \mathrm{~s}$ at $21^{\circ} \mathrm{C}$. The AP surface was incubated with Tris buffer throughout the experiment. Results are means of three experiments. ${ }^{*} P<0.05$ compared with AII alone.

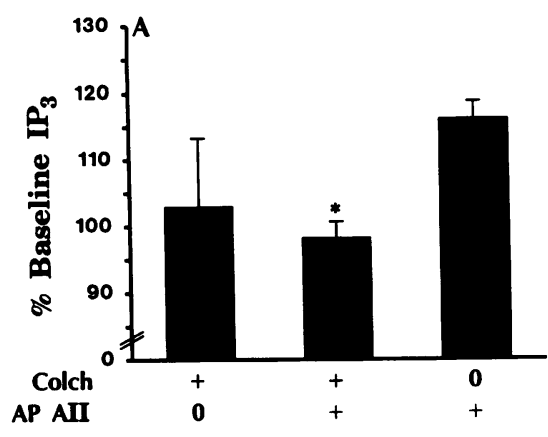

Figure 9. Effect of colchicine (Colch) on AP AII-induced $\mathrm{IP}_{3}$ formation. Proximal tubule cells were incorporated with myo-[2-

${ }^{3} \mathrm{H}$ ] inositol as described in Methods. In $A$, confluent proximal tubule cell monolayers on permeable supports were incubated with $10^{-8} \mathrm{M}$ colchicine or Tris buffer

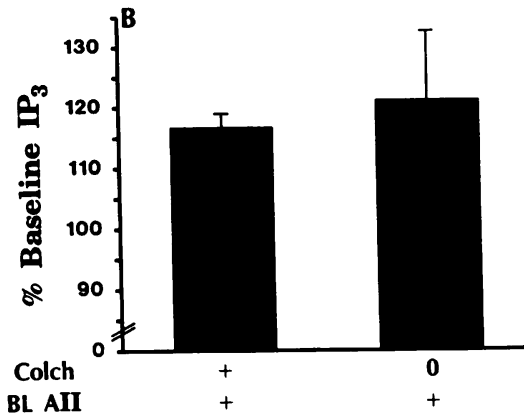
for $2 \mathrm{~h}$ at $37^{\circ} \mathrm{C}$, washed with phosphate-buffered saline, and exposed to AP $10^{-7} \mathrm{M}$ AII or Tris buffer for $30 \mathrm{~s}$ at $21^{\circ} \mathrm{C}$. $\mathrm{IP}_{3}$ was extracted and measured as described in Methods. Results are means of four to eight experiments. In $B$, confluent proximal tubule cell monolayers on permeable supports were incubated with $10^{-8} \mathrm{M}$ colchicine or Tris buffer for $2 \mathrm{~h}$ at $37^{\circ} \mathrm{C}$, washed with phosphate-buffered saline, and exposed to $\mathrm{BL} 10^{-7} \mathrm{M}$ AII or Tris buffer for $30 \mathrm{~s}$ at $21^{\circ} \mathrm{C}$. $\mathrm{IP}_{3}$ was extracted and measured as described in Methods. Results are means of four experiments. ${ }^{*} P<0.05$ compared with AII alone.

Many ligands and receptors are transported within endosomes after binding ( 31 ), and the AP membrane is associated with a highly developed cytoskeleton (32), which may facilitate endosome trafficking. To investigate the role of cytoskeletal structures in AP AII receptor signaling, we determined the effect of two agents that interfere with cytoskeletal function at different sites: colchicine (an agent that disrupts microtubules [33]) and cytochalasin D (an agent that disrupts microfilaments [34]). Fig. $9 A$ reveals that colchicine did not alter basal $\mathrm{IP}_{3}$ levels (baseline $=572.0 \pm 54.3 \mathrm{cpm}$ per well). However, colchicine preincubation prevented AP AII-mediated $\mathrm{IP}_{3}$ formation (Fig. $9 \mathrm{~A}$ ) but had no effect on BL AII-mediated $\mathrm{IP}_{3}$ formation (Fig. $9 \mathrm{~B}$, baseline $=415.8 \pm 38.5 \mathrm{cpm}$ per well). Fig. 10 demonstrates that cytochalasin D inhibited AP AII-mediated $\mathrm{IP}_{3}$ formation (Fig. $10 \mathrm{~A}$, baseline $=558.9 \pm 35.2 \mathrm{cpm}$ per well) and had no effect on BL AII-mediated $\mathrm{IP}_{3}$ formation (Fig. $10 \mathrm{~B}$, baseline $=570.3 \pm 76.8 \mathrm{cpm}$ per well). These data indicate that neither colchicine nor cytochalasin $\mathrm{D}$ were toxic in the concentrations used in these studies and that microtubules and microfilaments are required for AP AII-induced PLC activation.

\section{Discussion}

The results of the present study demonstrated that rat proximal tubule cells cultured on permeable supports retained the morphological, biochemical, and functional characteristics of proximal tubule cells in vivo. Proximal tubule cells were unlikely to permit paracellular ligand leakage as evidenced by electron microscopy and impediment to paracellular inulin or inositol movement. Exposure of either AP or BL AII receptors to AII resulted in PLC activation, as indicated by increased $\mathrm{IP}_{3}$ forma- 

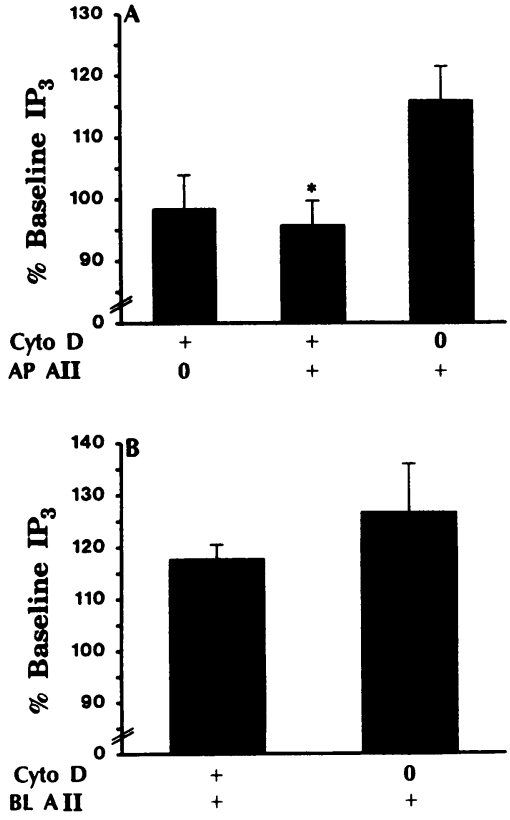

Figure 10. Effect of cytochalasin $\mathrm{D}($ Cyto D $)$ on AII-induced $\mathrm{IP}_{3}$ foundation. Proximal tubule cells were incorporated with myo-[2${ }^{3} \mathrm{H}$ ] inositol as described in Methods. In $A$, confluent proximal tubule cell monolayers on permeable supports were incubated with $2 \mu \mathrm{M}$ cytochalasin D for 30 min at $37^{\circ} \mathrm{C}$, washed with phosphate-buffered saline, and exposed to AP $10^{-7} \mathrm{M}$ AII or Tris buffer for $30 \mathrm{~min}$ at $21^{\circ} \mathrm{C} . \mathrm{IP}_{3}$ was extracted and measured as described in Methods. Results are means of four experiments. In $B$, confluent proximal tubule

cell monolayers on permeable supports were incubated with $2 \mu \mathrm{M}$ cytochalasin D or Tris buffer for $30 \mathrm{~min}$ at $37^{\circ} \mathrm{C}$, washed with phosphate-buffered saline, and exposed to BL $10^{-7} \mathrm{M}$ AII or Tris buffer for $30 \mathrm{~s}$ at $21^{\circ} \mathrm{C} . \mathrm{IP}_{3}$ was extracted and measured as described in Methods. Results are means of four experiments. ${ }^{*} P<0.05$ compared with AII alone.

tion. AII-induced PLC activation was mediated by specific $\mathrm{AT}_{1}$ receptors since AII-induced $\mathrm{IP}_{3}$ generation was prevented by the nonpeptide antagonist DuP 753. Furthermore, the AP signal did not result from paracellular ligand leak to BL receptors, as AP addition of AII elicited PLC signals in the presence of BL receptor inhibition with the peptide antagonist Sar-Leu AII or DuP 753. Finally, agents that inhibited endocytosis or cytoskeletal function inhibited AP, but not BL PLC activation.

Results from in vivo experiments have demonstrated a biphasic effect of AII on proximal tubule sodium absorption, with picomolar AII concentrations stimulating sodium absorption and micromolar AII concentrations causing decreased sodium absorption $(1,3)$. Our results indicate that AP $10^{-7} \mathrm{M}$ AII enhanced sodium absorption in cultured proximal tubule cells (Fig. 3).

Our data revealed that AII, at concentrations that enhanced ${ }^{22} \mathrm{Na}$ transport, increased $\mathrm{IP}_{3}$ by up to $26.6 \%$ above baseline in cultured proximal tubule cells. It is unclear, however, whether the early (30-s AII incubation) $\mathrm{IP}_{3}$ increase was the predominant signal that caused the ${ }^{22} \mathrm{Na}$ transport that occurred 20-30 min later. Although studies by Liu and Cogan (15) suggest that AII-induced bicarbonate flux in microperfused rat proximal tubules may have been associated with activation of PLC, other investigators have not identified AII-mediated activation of PLC in proximal tubule cells $(16,17)$. Although the explanation for this discrepancy is not readily apparent, species differences ( rat vs. rabbit) could be one factor. A more likely explanation, however, is that experimental conditions have varied between studies. Whereas prior studies were conducted with proximal tubule cell suspensions (17) or proximal tubule cells grown on impermeable surfaces (16), we used proximal tubule cells that were cultured on permeable supports. In contrast to cells cultured on impermeable supports, there is enhanced growth and differentiation of proximal tubule cells cultured on permeable supports (21).

We were concerned by the modest $\mathrm{IP}_{3}$ response to AP AII, as studies with AII in other tissues have yielded greater $\mathrm{IP}_{3}$ responses $(13,14,25,35)$. One potential explanation for the weaker $\mathrm{IP}_{3}$ signal in proximal tubule cells is that AII may elicit stronger PLC signals in $S_{1}$ proximal tubule segments, since this segment demonstrates both the greatest AII receptor density and the largest bicarbonate flux in response to AII (4). Because our method of isolating proximal tubules also included $\mathrm{S}_{2}$ and $\mathrm{S}_{3}$ segments, the PLC signal could be "diluted" by inclusion of less active $S_{2}$ and $S_{3}$ portions. Another possibility for the modest $\mathrm{IP}_{3}$ signal in proximal tubule cells is that $\mathrm{IP}_{3}$ degradation by phosphatases may be enhanced in these cells. In support of this contention, we noted an additional $15.2 \%$ increase in AP AIIinduced $\mathrm{IP}_{3}$ levels after 20 min incubation with $10 \mathrm{mM}$ lithium chloride (data not shown), an agent that inhibits myo-inositol1-phosphatase activity (36). Although the use of lithium would have resulted in consistently higher inositol phosphate values, we chose to perform studies without lithium because this agent may also affect other interrelated, AII-responsive enzymes, such as adenylyl cyclase $(37,38)$. However, because only small changes in $\mathrm{IP}_{3}$ are necessary to cause intracellular calcium mobilization (39), we therefore considered the observed AII-induced $\mathrm{IP}_{3}$ increase to be biologically relevant.

The relation between duration of AII exposure and peak $\mathrm{IP}_{3}$ formation in proximal tubule cells is similar to the time dependency observed in vascular smooth muscle cells $(13,40)$. In both systems there is an early $\mathrm{IP}_{3}$ response that decays over 30-60 s, with no subsequent increases. In contrast, the time dependency between AII and $\mathrm{IP}_{3}$ differs in adrenal glomerulosa cells, in which there is a biphasic AII response (14). In these cells there is an early $\mathrm{IP}_{3}$ peak (similar to vascular smooth muscle and proximal tubule cells), followed by a second $\mathrm{IP}_{3}$ peak, which is characterized by sustained $\mathrm{IP}_{3}$ formation for $\geq 30 \min (14,41)$.

To be certain that there was specific coupling of proximal tubule AII receptors to PLC, we performed studies with AII receptor antagonists. Incubation with either the peptide antagonist Sar-Leu AII (data not shown) or the nonpeptide inhibitor DuP 753 prevented AII-induced $\mathrm{IP}_{3}$ formation (Fig. 6). These data confirm that there is specific coupling between AII receptors and PLC in cultured rat proximal tubule cells. Although previous studies with $\mathrm{AP}$ and $\mathrm{BL}$ proximal tubule membrane preparations documented more than one AII receptor subtype (9), inhibition of AII-generated $\mathrm{IP}_{3}$ with DuP 753 suggested that the PLC signal was mediated by $\mathrm{AT}_{1}$ receptors $(42,43)$.

Our studies also demonstrated that AII-induced PLC signals were elicited by both AP and BL receptors. These results are consistent with studies demonstrating that AII receptors have been identified on both the AP and BL proximal tubule cell membranes $(8,9,18)$, and AII elicits bicarbonate absorption when added to AP or BL sites of microperfused proximal tubules (4). Although BL receptors are exposed to AII from circulating plasma, the source of AII that could activate AP receptors has only recently been confirmed. Seikaly et al. (44) have shown that AII undergoes glomerular filtration and is present in the proximal tubule lumen in concentrations that were comparable to the AP AII concentrations used in our studies. Furthermore, we observed that separate AP and BL incubations with equivalent concentrations of AII resulted in greater $\mathrm{BL} \mathrm{IP}_{3}$ formation. 
The results of three studies indicate that the PLC signal elicited from AP AII receptors was mediated by AP AII receptors rather than by paracellular ligand leak to BL sites. In this regard, transmission electron micrographs revealed proximal tubule cell monolayers with well-defined tight junctions. In addition, significant inulin or inositol leak from AP to $\mathrm{BL}$ buffer was not observed. Furthermore, exposure of AP receptors to AII when the BL receptors were occupied by AII receptor antagonists still resulted in PLC signaling. These data confirm that the AP AII receptor is coupled to PLC.

Since AP AII receptors have been shown to be degradative receptors (11) and since AII receptors require endocytosis for signaling in vascular smooth muscle (19) and adrenal glomerulosa (20) cells, we questioned whether there was an endocytosis requirement for signaling on the AP proximal tubule surface. To answer this question, we compared AP and BL responses with AII in the presence of phenylarsine oxide, colchicine, and cytochalasin D. The results indicated that receptor-mediated endocytosis through a cytoskeletal domain is required for AIIinduced PLC activation from AP, but not BL sites. This conclusion is consistent with recently described data that the cytoskeleton is not merely a structural cell component but also plays a dynamic role in protein and glycoprotein targeting (4548 ). In addition, differences between the cytoskeletal dependence of AP and BL AII receptor endocytosis are consistent with morphological findings that demonstrate highly developed cytoskeletal components in the AP domain of polarized epithelial cells (32).

A requirement for cytoskeleton-dependent endocytosis is not unique for AP AII receptor-mediated PLC activation. Other AP functions such as epidermal growth factor receptormediated ricin uptake (49), glucose (50-53), and water (5457) transport also require cytoskeleton-dependent endocytosis. In the case of glucose transport, microfilament disruption with cytochalasin B resulted in impaired glucose transporter trafficking and diminished glucose uptake (50-53). Toad bladder studies have revealed that water transport is dependent upon water channel movement through the cytoskeleton, since water transport was inhibited after disruption of either microfilaments (54-57) or microtubules $(54,55,57)$. Although endocytosis through cytoskeletal domains appears to be required for a number of AP functions, there is little information about the role of the cytoskeleton in receptor-mediated signal transduction. Our data revealed that the cytoskeleton was not required for BL AII receptor activation of PLC, but AP activation of PLC was cytoskeleton dependent in proximal tubule cells.

Although our studies do not indicate the site to which AP AII or AII receptors are directed, it is unlikely that PLC is activated after ligand transcytosis and binding to BL receptors, since AP AII incubation was associated with $\mathrm{IP}_{3}$ formation in the presence of BL receptor inhibition (Fig. 7). Since endocytosis-dependent signal transduction was observed in vascular smooth muscle (19) and adrenal glomerulosa (20) cells, it has been speculated that $\mathrm{IP}_{3}$ may be formed after activation of endosomal membrane-bound PLC (20). Such a mechanism is also plausible in proximal tubule cells. In conclusion, our studies suggest that the mechanism of AII function in proximal tubule cells is more complex than previously recognized. In cultured rat proximal tubule cells AII is coupled to PLC, binding to either AP or BL AII receptors results in PLC activation, and cytoskeleton-dependent endocytosis is required for AP, but not BL, AII receptor-mediated PLC activation.

\section{Acknowledgments}

We thank Vicky Maltezos and Jacqueline Smith for preparation of the manuscript and Rolf Dahl for the electron microscopy studies.

This work was supported by the National Institutes of Health grants HL-37694, DK-35098, and DK-08465, and by the National Kidney Foundation of Colorado.

\section{References}

1. Harris, P. J., and L. G. Navar. 1985. Tubular transport responses to angiotensin II. Am. J. Physiol. 248:F621-F630.

2. Hall, J. E. 1986. Control of sodium excretion by angiotensin II: intrarenal mechanisms and blood pressure regulation. Am. J. Physiol. 250:R960-R972.

3. Schuster, V. L., J. P. Kokko, and H. R. Jacobson. 1984. Angiotensin II directly stimulates sodium transport in rabbit proximal convoluted tubules. $J$. Clin. Invest. 73:507-515.

4. Liu, F. Y., and M. G. Cogan. 1988. Angiotensin Il stimulation of hydrogen ion secretion in the rat early proximal tubule. J. Clin. Invest. 82:601-607.

5. Gesek, F. A., and A. C. Schoolwerth. 1990. Hormonal interactions with the proximal $\mathrm{Na}^{+}-\mathrm{H}^{+}$exchanger. Am. J. Physiol. 258:F514-F521.

6. Saccomani, G., K. D. Mitchell, and L. G. Navar. 1990. Angiotensin Il stimulation of $\mathrm{Na}^{+}-\mathrm{H}^{+}$exchange in proximal tubule cells. Am. J. Physiol. 258:F1188-F1195.

7. Geibel, J., G. Giebisch, and W. F. Boron. 1990. Angiotensin II stimulates both $\mathrm{Na}^{+}-\mathrm{H}^{+}$exchange and $\mathrm{Na}^{+} / \mathrm{HCO}_{3}$ cotransport in the rabbit proximal tubule. Proc. Natl. Acad. Sci. USA. 87:7917-7920.

8. Brown, G. P., and J. G. Douglas. 1982. Angiotensin II binding sites on isolated rat renal brush border membranes. Endocrinology. 111:1830-1836.

9. Douglas, J. G. 1987. Angiotensin receptor subtypes of the kidney cortex. Am. J. Physiol. 253:F1-F7.

10. Morel, F. 1981. Sites of hormone action in the mammalian nephron. Am. J. Physiol. 240:F159-F164.

11. Carone, F. A., and D. R. Peterson. 1980. Hydrolysis and transport of small peptides by the proximal tubule. Am. J. Physiol. 238:F151-F158.

12. Liu, F. Y., and M. G. Cogan. 1989. Angiotensin II stimulates early proximal bicarbonate absorption in the rat by decreasing cyclic adenosine monophosphate. J. Clin. Invest. 84:83-91.

13. Alexander, R. W., T. A. Brock, M. A. Gimbrone, and S. E. Rittenhouse. 1985. Angiotensin increases inositol triphosphate and calcium in vascular smooth muscle. Hypertension (Dallas). 7:447-451.

14. Balla, T., A. J. Baukal, G. Guillemette, and K. J. Catt. 1988. Multiple pathways of inositol polyphosphate metabolism in angiotensin-stimulated adrenal glomerulose cells. J. Biol. Chem. 263:4083-4091.

15. Liu, F. Y., and M. G. Cogan. 1990. Role of protein kinase C in proximal bicarbonate absorption and angiotensin signaling. Am. J. Physiol. 258:F927F933.

16. Welsh, C., G. Dubyak, and J. G. Douglas. 1988. Relationship between phospholipase $C$ activation and prostaglandin $\mathrm{E}_{2}$ and cyclic adenosine monophosphate production in rabbit tubular epithelial cells. J. Clin. Invest. 81:710-719.

17. Sekar, M. C., M. Yang, E. Meezan, and D. J. Pillion. 1990. Angiotensin Il and bradykinin stimulate phosphoinositide breakdown in intact rat kidney glomeruli but not in proximal tubules: glomerular response modulated by phorbol ester. Biochem. Biophys. Res. Commun. 166:373-379.

18. Brown, G. P., and J. G. Douglas. 1983. Angiotensin II-binding sites in rat and primate isolated renal tubular basolateral membranes. Endocrinology. 112:2007-2014

19. Griendling, K. K., P. Delafontaine, S. E. Rittenhouse, M. A. Gimbrone, R. W. Alexander. 1987. Correlation of receptor sequestration with sustained diacylglycerol accumulation in angiotensin II-stimulated cultured vascular smooth muscle cells. J. Biol. Chem. 262:14555-14562.

20. Hunyady, L., F. Merelli, A. J. Baukal, T. Balla, and K. J. Catt. 1991. Agonist-induced endocytosis and signal generation in adrenal glomerulose cells. J. Biol. Chem. 266:2783-2788.

21. Handler, J. S. 1986. Studies of kidney cells in culture. Kidney Int. 30:208215.

22. Ford, S. M., P. D. Williams, S. Grassl, and P. D. Holohan. 1990. Transepithelial acidification by cultures of rabbit proximal tubules grown on filters. Am. J. Physiol. 259:C103-C109.

23. Vinay, P., A. Gougoux, and G. Lemieux. 1981. Isolation of a pure suspension of rat proximal tubules. Am. J. Physiol. 241:F403-F411.

24. Lowry, O. H., N. J. Rosebrough, A. L. Farr, and R. J. Randall. 1951. Protein measurement with Folin phenol reagent. J. Biol. Chem. 193:265-275.

25. Ullian, M. E., and S. L. Linas. 1990. Angiotensin II surface receptor coupling to inositol triphosphate formation in vascular smooth muscle cells. $J$. Biol. Chem. 265:195-200.

26. Berridge, M. J., R. M. C. Dawson, C. P. Downes, J. P. Heslop, and R. F. Irvine. 1983. Changes in the levels of inositol phosphates after agonist-dependent hydrolysis of membrane phosphoinositides. Biochem. J. 212:473-482. 
27. Chung, S. D., A. Naheed, D. Livingston, S. Hiller, and M. Taub. 1982 Characterization of primary rabbit kidney cultures that express proximal tubule functions in a hormonally defined medium. J. Cell Biol. 95:118-126.

28. Wilson, P. D., M. A. Dillingham, R. Breckon, and R. J. Anderson. 1985. Defined human renal tubular epithelia in culture: growth, characterization, and hormonal response. Am. J. Physiol. 248:F436-F443.

29. Gesek, F. A., D. W. Wolff, and J. W. Strandhoy. 1987. Improved separation method for rat proximal and distal renal tubules. Am. J. Physiol. 253:F358F365.

30. Ullian, M. E., and S. L. Linas. 1989. Role of receptor cycling in the regulation of angiotensin II surface receptor number and angiotensin II uptake in rat vascular smooth muscle cells. J. Clin. Invest. 84:840-846.

31. Stahl, P., and A. L. Schwartz. 1986. Receptor-mediated endocytosis. J. Clin. Invest. 77:657-662.

32. Rodriguez-Boulan, E., and W. J. Nelson. 1989. Morphogenesis of the polarized epithelial cell phenotype. Science (Wash. DC). 245:718-725.

33. Rindler, M. J., I. E. Ivanov, and D. D. Sabatini. 1987. Microtubule-acting drugs lead to the nonpolarized delivery of the influenza hemagglutinin to the cell surface of polarized Madin-Darby canine kidney cells. J. Cell Biol. 104:231-241.

34. Yahara, I., F. Harada, S. Sekita, K. Yoshihira, and S. Natori. 1982. Correlation between effects of 24 different cytochalasins on cellular structures and cellular events and those on actin in vivo. J. Cell Biol. 92:69-78.

35. Benabe, J. E., L. A. Spry, and A. R. Morrison. 1982. Effects of angiotensin II on phosphatidylinositol and polyphosphoinositide turnover in rat kidney. $J$. Biol. Chem. 257:7430-7434.

36. Hallcher, L. M., and W. R. Sherman. 1980. The effects of lithium ion and other agents on the activity of myo-inositol-1-phosphatase from bovine brain. $J$. Biol. Chem. 255:10896-10901.

37. Dousa, T. P. 1974. Cellular action of antidiuretic hormone in nephrogenic diabetes insipidus. Mayo Clin. Proc. 49:188-199.

38. Cogan, E., and M. Abramow. 1986. Inhibition by lithium of the hydroosmotic action of vasopressin in the isolated perfused cortical collecting tubule of the rabbit. J. Clin. Invest. 77:1507-1514.

39. Meyer T., D. Holowka, and L. Stryer. 1988. Highly cooperative opening of calcium channels by inositol 1,4,5-trisphosphate. Science (Wash. DC). 240:653-656.

40. Smith, J. B., L. Smith, E. R. Brown, D. Barnes, M. A. Sabir, J. S. Davis and R. V. Farese. 1984. Angiotensin II rapidly increases phosphatidate-phosphoinositide synthesis and phosphoinositide hydrolysis and mobilizes intracellular calcium in cultured arterial muscle cells. Proc. Natl. Acad. Sci. USA. 81:78127816.

41. Kojima, I., K. Kojima, D. Kreutter, and H. Rasmussen. 1984. The temporal integration of the aldosterone secretory response to angiotensin occurs via two intracellular pathways. J. Biol. Chem. 259:14448-14457.

42. Chiu, A. T., D. E. McCall, P. E. Aldrich, and P. B. M. W. M. Timmer- mans. 1990. $\left[{ }^{3} \mathrm{H}\right]$ DuP 753, a highly potent and specific radioligand for the angiotensin II-1 receptor subtype. Biochem. Biophys. Res. Commun. 172:1195-1202.

43. Dudley, D. T., R. L. Panek, T. C. Major, G. H. Lu, R. F. Bruns, B. A Klinkefus, J. C. Hodges, and R. E. Weishaar. 1990. Subclasses of angiotensin II binding sites and their functional significance. Mol. Pharmacol. 38:370-377.

44. Seikaly, M. G., B. S. Arant, and F. D. Seney. 1990. Endogenous angiotensin concentrations in specific intrarenal fluid compartments of the rat. J. Clin. Invest. 86:1352-1357.

45. Ojakian, G. K., and R. Schwimmer. 1988. The polarized distribution of an apical cell surface glycoprotein is maintained by interactions with the cytoskeleton of Madin-Darby canine kidney cells. J. Cell Biol. 107:2377-2387.

46. Gutmann, E. J., J. L. Niles, R. T. McCluskey, and D. Brown. 1989. Colchicine-induced redistribution of an apical membrane glycoprotein (gp 330) in proximal tubules. Am. J. Physiol. 257:C397-C407.

47. Breitfeld, P. P., W. C. McKinnon, and K. E. Mostov. 1990. Effect of nocodazole on vesicular traffic to the apical and basolateral surfaces of polarized MDCK cells. J. Cell Biol. 111:2365-2373.

48. Kaufman, S. S., P. L. Blain, J. H. Y. Park, and D. J. Tuma. 1990. Altered role of microtubules in asialoglycoprotein trafficking in developing liver. Am. J. Physiol. 258:G129-G137.

49. Sandvig, K., and B. van Deurs. 1990. Selective modulation of the endocytic uptake of ricin and fluid phase markers without alteration in transferrin endocytosis. J. Biol. Chem. 265:6382-6388.

50. Bloch, R. 1973. Inhibition of glucose transport in the human erythrocyte by cytochalasin B. Biochemistry. 12:4799-4801

51. Wardzala, L. J., S. W. Cushman, and L. B. Salans. 1978. Mechanism of insulin action on glucose transport in the isolated rat adipose cell. J. Biol. Chem. 253:8002-8005.

52. Sternlicht, E., R. J. Barnard, and G. K. Grimditch. 1988. Mechanism of insulin action on glucose transport in rat skeletal muscle. Am. J. Physiol. 254:E633-E638

53. King, P. A., M. F. Hirshman, E. D. Horton, and E. S. Horton. 1989. Glucose transport in skeletal muscle membrane vesicles from control and exercised rats. Am. J. Physiol. 257:C1128-C1134.

54. Kachadorian, W. A., S. J. Ellis, and J. Muller. 1979. Possible roles for microtubules and microfilaments in ADH action on toad urinary bladder. Am. J. Physiol. 236:F14-F20.

55. Palmer, L. G., and M. Lorenzen. 1983. Antidiuretic hormone-dependent membrane capacitance and water permeability in the toad urinary bladder. Am. J. Physiol. 244:F195-F204.

56. Pearl, M., and A. Taylor. 1983. Actin filaments and vasopressin-stimulated water flow in toad urinary bladder. Am. J. Physiol. 245:C28-C39.

57. Valenti, G., J. S. Hugon, and J. Bourguet. 1988. To what extent is microtubular network involved in antidiuretic response? Am. J. Physiol. 255:F1098F1106. 